Suyanto $^{1}$, Andreawan Susanto ${ }^{2}$

${ }^{1,2}$ Faukultas IImu Keperawatan Universitas Islam Sultan Agung Semarang

\title{
ABSTRAK
}

Diabetes melitus merupakan penyakit kronik yang dapat menyebabkan beberapa komplikasi. Salah satu komplikasi pada penderita diabetes melitus adalah neuropati perifer diabetik. Sekitar $60-70 \%$ penderita DM mengalami hal tersebut. Faktorfaktor yang berpengaruh terhadap kejadian neuropati perifer diabetik antara lain peningkatan umur, lama menderita DM, dan rendahnya kontrol gula darah. Tujuan dari penelitian ini adalah untuk mengetahui hubungan antara lama menderita DM dengan kejadian neuropati perifer diabetik. Penelitian ini menggunakan design cross sectional dengan jumlah responden sebanyak 79 orang dengan menggunakan simple random sampling. Hasil uji chi square menunjukkan tidak ada hubungan antara umur dan lama menderita DM dengan kejadian neuropati perifer diabetik ( $p$ value $>0,05$ ). Sehingga dapat disimpulkan bahwa umur dan lama menderita DM merupakan faktor resiko yang tidak berhubungan dengan terjadinya neuropati perifer diabetik. Untuk itu perlu adanya penelitian selanjutnya untuk melihat faktor lain seperti umur dan rendahnya kontrol gula darah.

Keywords : diabetes melitus, neuropati perifer diabetik, lama menderita DM, umur

\section{FACTORS RELATED TO DIABETIC PERIPHERAL NEUROPATHY}

\begin{abstract}
Diabetic mellitus is a crhonic disease and have a complications. One of the complication is diabetic peripheral neuropathy. 60$70 \%$ patient with diabetic mellitus also has diabetic peripheral neuropathy. Factors that contribute of diabetic peripheral neuropathy incident are length of diabetes, ages, and poor of glucose control. This study aims to knew correlate beetwen length of diabetes with diabetic peripheral neuropathy incident.

Methodology: This study used cross sectional design with 79 respondents and recruited by simple random sampling methode. Data were collected from patients with diabetic mellitus. Diabetic peripheral neuropathy was measured by diabetic neuropathy symptom (DNS) . Chi square test analysis showed no significant correlate beetwen age and length of diabetes with diabetic peripheral neuropathy incident ( $p$ value $>0.05$ ). It can be inferred that age and length of diabetes aren't risk factor that contributed diabetic peripheral neuropathy incident. Therefore, need more reseacrh to correlate beetwen diabetic peripheral neuropathy incident with the other factors.
\end{abstract}

Key words $\quad$ : Diabetic mellitus, Diabetic peripheral neuropathi, Age, Length of diabetes

Corresponding Author:

Suyanto $^{1}$, Fakultas Ilmu Keperawatan Universitas Islam Sultan Agung; e-mail suyanto@unissula.ac.id

\section{PENDAHULUAN}

Diabetes melitus merupakan kondisi dimana terjadi gangguan dalam mengubah glukosa menjadi energi sehingga terjadi peningkatan berlebih glukosa dalam darah (hiperglikemia) dan dapat juga memunculkan gejala (Day, 2001). Penderita Diabetes melitus yang melakukan kontrol gula dengan rutin dan baik akan menyebabkan timbulnya komplikasi vaskular. Komplikasi vaskular ini dibedakan menjadi makrovaskular (penyakit jantung koroner, stroke) dan mikrovaskular (retinopati, nefropati, neuropati) (Black, J.M., \& Hawks, 2009). Komplikasi mikrovaskular berupa neuropati dapat berakibat terjadinya gangguan pada kaki diabetes mulai dari terjadinya luka kaki / tungkai sampai kemungkinan terjadinya amputasi pada kaki/tungkai tersebut(Ignatavicius, D.D., \& Workman, 2006). 
Insidensi neuropati diabetik terjadi antara 60\% sampai 70\% pada pasien DM tipe I dan tipe II dengan adanya komplikasi neurologi (LeMone, 2008). Studi cohort terhadap 4400 pasien di Belgia, menemukan bahwa 7,5\% responden memiliki neuropati pada awal didiagnosis DM. Setelah 25 tahun, neuropati naik menjadi $45 \%$. Insidensi di Inggris, prevalensi neuropati diabetik di antara populasi pasien di rumah sakit tercatat sekitar $29 \%$ mengalami neuropati perifer diabetik (Argoff, C.E., Cole,B.E., Fishbain, D.A., \& Irving, 2006).

Faktor-faktor yang berhubungan dengan neuropati menurut (Black, J.M., \& Hawks, 2009) antara lain yakni insufisiensi pembuluh darah, peningkatan glukosa darah kronis dan faktor metabolik. Teori lain menyatakan bahwa faktor resiko lain yang dapat menyebabkan neuropati diabetik menurut (Katulanda, P.,Priyanga,R.,Ranil,J.,Gidwin,R.C.,Rezvi,S.,David, 2012) antara lain peningkatan umur, lama waktu menderita DM dan rendahnya kontrol gula darah. Survei awal yang telah dilakukan pada pasien di Rumah Sakit Umum Daerah Demak didapatkan data bahwa dari 7 orang pasien rawat jalan dengan DM, 4 (empat) pasien mengalami gejala neuropati diabetik berupa mati rasa pada kaki.

Penelitian mengenai komplikasi diabetes mellitus banyak dilakukan tetapi penelitian mengenai faktor yang berhubungan dengan kejadian neuropati perifer diabetik belum banyak dibahas. Adapun tujuan dari penelitian ini adalah untuk mengetahui hubungan faktor-faktor yang berhubungan dengan neuropati perifer diabetik

\section{METODE}

Penelitian ini merupakan penelitian observasional dengan pendekatan cross sectional. Sebanyak 79 responden yang dijadikan sebagai sampel dengan tehnik pengambilan sampel berupa simple random sampling. Kriteria inklusi sampel pada penelitian ini adalah seluruh pasien DM tipe 2 yang berobat di Poli Klinik RSUD Demak. Instrumen yang digunakan untuk menilai neuropati perifer diabetik adalah diabetic neuropathy symptom (DNS).

Instrumen DNS merupakan salah satu instrumen yang digunakan untuk menilai kejadian neuropati perifer diabetik. Skor total DNS adalah 4, jika penderita DM memiliki skor 1 sudah termasuk kedalam neuroapti perifer diabetik(Meijer, J.W.K., Bosma, E., Lefrandt, J.D., Links, T.P., Smith, A.J., Steward, 2002). Di Indonesia, instrumen DNS telah diuji sensitivitas dan spesifitas pada untuk menilai gejala neuropati perifer diabetik pasien DM dengan hasil $p$ value $<0.05$ (Mediastuti, 2003). Analisis data penelitian ini menggunakan uji chi square dengan aplikasi software komputer.

\section{HASIL}

Jenis Kelamin

Tabel 4.1 Distribusi frekuensi responden berdasarkan jenis kelamin Di RSUD Demak, $2016(n=79)$

\begin{tabular}{lcc}
\hline Variabel & Jumlah & Prosentase (\%) \\
\hline Jenis Kelamin & & \\
Laki-laki & 33 & 41,8 \\
Perempuan & 46 & 59,2 \\
Total & 79 & 100 \\
\hline
\end{tabular}


Tabel 4.1 menunjukkan jenis kelamin yang paling dominan adalah perempuan sebanyak 46 responden $(59,2 \%)$.

\section{Umur dan Lama menderita DM}

Tabel 4.2 Distribusi responden berdasarkan rata-rata umur dan lama menderita DM Di RSUD Demak,

\begin{tabular}{cccccc}
$2016(\mathrm{n}=79)$ & \multicolumn{1}{l}{} \\
\hline Variabel & Mean $\mathbf{S}$ SD & Median & Min - Maks & $\mathbf{9 5 \% ~ C l}$ & $\boldsymbol{n}$ \\
\hline Umur & $53,16 \pm \mathbf{8 , 7 5}$ & 54 & $30-71$ & $51,2-55,13$ & 79 \\
Lama menderita DM & $6,19 \pm \mathbf{3 , 8}$ & 6 & $1-16$ & $5,3-7,0$ & 79
\end{tabular}

Tabel 4.2 menunjukan rata-rata umur responden adalah 53 tahun,umur paling muda adalah 30 tahun dan yang tertua adalah 71 tahun. Rata-rata lama responden menderita DM adalah 6 tahun, responden terlama menderita DM adalah 16 tahun, dan terendah adalah 1 tahun

Kejadian neuropati perifer diabetik

Tabel 4.3 Distribusi frekuensi responden berdasarkan kejadian neuropati perifer diabetik Di RSUD Demak, $2016(n=79)$

\begin{tabular}{ccc}
\hline Variabel & Jumlah & Prosentase (\%) \\
\hline Ya & 75 & 94,9 \\
Tidak & 4 & 5,1 \\
Total & 79 & 100
\end{tabular}

Tabel 4.3 menunjukan 75 (94,9\%) responden mengalami neuropati perifer diabetik.

Hubungan antara umur dengan kejadian neuropati perifer diabetik

Tabel 4.4 Analisis hubungan antara umur dengan kejadian neuropati perifer diabetik Di RSUD Demak,

\begin{tabular}{cccc}
$2016(\mathrm{n}=79)$ & & \\
\hline Variabel & \multicolumn{2}{c}{ Kejadian neuropati perifer diabetik } & p value \\
\hline Umur & Terjadi & Tidak terjadi & 0,58 \\
\hline $30-53$ & $2(5,9 \%)$ & $32(94,1 \%)$ & \\
$54-71$ & $2(4,4 \%)$ & $43(95,6 \%)$ & \\
Total & $4(5,1 \%)$ & $75(94,9 \%)$ &
\end{tabular}

Tabel 4.4 dengan uji chi square menunjukkan nilai $p$ value 0,58 ( $p$ value $>0,05$ ) sehingga dapat disimpulkan tidak ada hubungan antara lama menderita DM dengan kejadian neuropati perifer diabetik.

Hubungan antara lama menderita DM dengan kejadian neuropati perifer diabetik

Tabel 4.5 Analisis hubungan antara lama menderita DM dengan kejadian neuropati perifer diabetik Di RSUD Demak, 2016 ( $n=79)$

\begin{tabular}{cccc}
\hline Variabel & \multicolumn{2}{c}{ Kejadian neuropati perifer diabetik } & p value \\
\hline Lama menderita DM & Terjadi & Tidak terjadi & \\
\hline $1-6$ & $2(4,3 \%)$ & $44(95,7 \%)$ & 0,55 \\
$7-16$ & $2(6,1 \%)$ & $31(93,9 \%)$ &
\end{tabular}


Tabel 4.5 dengan uji chi square didapatkan hasil nilai $p$ value 0,55 ( $p$ value $>0,05$ ) sehingga dapat disimpulkan tidak ada hubungan antara lama menderita DM dengan kejadian neuropati perifer diabetik.

\section{PEMBAHASAN}

Hasil analisis data menunjukkan jenis kelamin perempuan paling banyak mengalami neuropati. Hasil ini sesuai dengan hasil penelitian terdahulu yang relevan yang menyatakan bahwa faktor resiko potensial neuropati diabetik lebih besar pada perempuan sebesar $78 \%$ dibandingkan responden lakilaki 22 \% (Booya, F., Bandarian, F., Larijani, B., Pajouhi, M., Nooraei, M, \& Lotfi, 2005). Hasil penelitian yang relevan mengenai pengaruh neuropati perifer, gender, dan obesitas pada postural stabilitas pasien dengan DM tipe 2 menyatakan bahwa sebanyak 107 responden dari 151 responden yang mengalami neuropati perifer diabetik adalah wanita. Penelitian lain dari (Aaberg, M. L., Burch, D. M., Hud, Z. R., \& Zacharias, 2008) menunjukkan bahwa dari total 376 responden yang mengalami neuropati perifer diabetik terdapat 220 responden (59\%) adalah wanita, akan tetapi onset terjadi neuropati perifer diabetik lebih banyak pada laki-laki.

Jumlah rata - rata umur responden pada penelitian ini yakni 53 tahun. Penelitian relevan lainnya bahwa pasien DM tipe 2 yang berumur kurang dari 70 tahun memiliki resiko lebih tinggi mengalami komplikasi mikrovaskuler seperti neuropati, retinopati, dan nefropati (Floch, J.P., Doucet, J., Bauduceau, B., \& Verny, 2013). Hasil penelitian ini tidak sesuai dengan penelitian sebelumnya yang menyatakan bahwa rata-rata usia penderita DM yang mengalami neuropati yakni berumur 55.1 tahun (Booya, F., Bandarian, F., Larijani, B., Pajouhi, M., Nooraei, M, \& Lotfi, 2005).

lansia yang mengalami penurunan sensasi kaki secara fisiologi terjadi sesuai dengan penambahan umur. Lansia yang mengalami DM, penurunan sensasi kakinya semakin cepat disamping karena proses menua yang fisiologis juga diperparah dengan adanya efek dari kondisi hiperglikemi kronis. Hal ini ditunjang dengan teori bahwa ada beberapa perubahan yang terjadi selama proses penuaan yang dapat memfasilitasi terjadinya neuropati diabetes antara lain termasuk peningkatan produksi glikosilasi - produk akhir canggih ( AGEs ), cacat dalam jalur poliol, perubahan pembuluh darah dan gangguan ketahanan saraf terhadap stres oksidatif (Belmin, 1996).

Hasil penelitian sebelumnya yang relevan menyatakan bahwa usia secara fisiologis mempengaruhi terjadinya perubahan kondisi pembuluh darah sehubungan dengan aterosklerosis. Aterosklerosis akan mengakibatkan aliran darah menjadi terhambat, sehingga hal tersebut akan berdampak terjadinya hipoksia jaringan yang akan berpengaruh terhadap fungsi sel syaraf (Andrade, Schalaad, Junior, \& Valen., 2004). Penurunan fungsi sel syaraf dapat mengurangi sensasi kaki pada lansia. Hasil penelitian yang relevan menyatakan bahwa pasien lanjut usia sangat berhubungan dengan penurunan sensasi kaki pada penderita neuropati diabetik ( $p$ value $<0.0001$ ) (Jaiwal et al, 2013).

Rata - rata lama menderita DM yakni 6 tahun. Ada 4 responden yang sudah mengalami neuropati perifer diabetik setelah 1 tahun menderita DM. Hasil ini sesuai dengan penelitian relevan lainnya yang menyatakan bahwa neuropati perifer diabetik yang dialami pasien DM terjadi sejak 3 - 5 tahun 
setelah terdiagnosa DM (Tesfaye, 2006). Lama waktu mengalami DM seiring dengan komplikasi, dalam arti semakin lama mengalami DM maka semakin tinggi pula kejadian komplikasi yang dialami oleh pasien. Menurut (Suzuki, E., Kashigawi, A., Nishio, Y., Egawa, K., Shimizu, S., \& Maegawa, 2001) menyatakan bahwa lamanya menderita DM dengan hiperglikemi mempengaruhi perubahan terhadap dinding pembuluh darah dan tekanan darah.

Pembuluh darah terdiri dari sel endotel yang melapisi bagian dalam lumen dari seluruh pembuluh darah dan berperan sebagai penghubung antara sirkulasi darah dan sel-sel otot polos pembuluh darah (Hayat, S.A., Patel,B., Khattar,R.S., \& Malik, 2004). Disamping berperan sebagai sawar fisik antara darah dan jaringan, sel endotel memfasilitasi berbagai fungsi yang kompleks dari sel otot polos pembuluh darah dan sel-sel didalam kompartemen darah (Haller, 1997). Hasil penelitian sebelumnya yang relevan menyatakan bahwa akibat dari hiperglikemik kronis dapat menyebabkan gangguan fungsi endotel (De Meyer, G.R., \& Herman, 1997). Sehingga dari rusaknya sel endotel tersebut akan menyebabkan penurunan fungsi dari sel syaraf perifer.

Hasil penelitian relevan lainnya menunjukkan lamanya waktu seseorang menderita DM dapat memperberat resiko komplikasi diabetes melitus diantaranya berupa neuropati dan ulkus diabetik(Bryant, R., \& Nix, 2007). Begitu pula menurut (Loughlin, D.T, \& Artlett, 2009) hiperglikemia yang berkepanjangan mengakibatkan terjadinya reaksi glikosilasi nonenzimatik mailard reaction antara protein dan reactive carbonyl dan dicarbonyl compound. Degradasi dari glikosilasi protein menghasilkan terbentuknya $\alpha$-dikarbonyl, 3-deoxyglucosone (3DG), yang kemudian akan membentuk advanced glication end products (AGEs), dan akhirnya menyebabkan terjadinya neuropati perifer diabetik.

Lama waktu terdiagnosa DM juga berkaitan dengan penurunan fungsi sel beta pankreas sehingga menimbulkan komplikasi yang secara umum terjadi pada pasien dengan lama sakit 5 - 10 tahun (Smeltzer, S.C., \& Bare, 2008). Hal ini sesuai dengan teori yang menyatakan bahwa penurunan fungsi sel beta pankreas akan berdampak pada produksi insulin. Berkurangnya jumlah produksi insulin didalam darah akan menurunkan proses glikolisis didalam sel. Akibatnya glukosa yang tidak terserap oleh sel akan menyebabkan peningkatan akumulasi glukosa pada pembuluh darah dan menjadikan kondisi hiperglikemik (Guyton, 2007).

Hasil penelitian ini memperlihatkan komplikasi sudah terjadi pada durasi waktu yang relatif lebih pendek setelah terdiagnosa DM. Asumsi peneliti, lama menderita DM yang disampaikan oleh responden belum sepenuhnya menggambarkan lama responden mengalami DM yang sebenarnya. Hal itu dikarenakan responden baru mengetahui mengalami DM setelah terjadi komplikasi dan mendatangi layanan kesehatan. Asumsi lain dikarenakan terbatasnya jumlah responden dan area penelitian yang hanya melibatkan satu rumah sakit, maka hal tersebut belum dapat menggambarkan proporsi mayoritas mengenai jenis kelamin pada penderita neuropati perifer diabetik. Hal tersebut yang menyebabkan tidak ada hubungan antara lama menderita DM dengan kejadian neuropati perifer diabetik.

Peran perawat dalam hal ini sebagai educator dan konselor dengan memberikan penjelasan kepada individu atau keluarga mengenai tanda dan gejala umum mengenai DM. Diharapkan dengan meningkatnya pengetahuan individu atau keluarga tersebut mengenai DM maka akan semakin meningkat pula perilaku individu atau keluarga untuk segera melakukan pemeriksaan ke pelayanan 
kesehatan setelah merasakan tanda dan gejala yang dirasakan. Semakin cepat penanganan DM maka diharapkan akan menurunkan resiko komplikasi yang lebih parah.

\section{SIMPULAN DAN IMPLIKASI PENELITIAN}

Simpulan dari penelitian ini adalah tidak ada hubungan antara umur, lama menderita DM dengan neuropati perifer diabetik ( $p$ value $>0.05$ ). Sebagian besar rerata responden menderita DM yakni selama 6 tahun dengan jenis kelamin perempuan yang paling banyak mengalami DM.

Hasil penelitian ini dapat dijadikan sebagai tambahan informasi mengenai faktor - faktor yang dapat menyebabkan terjadinya neuropati perifer diabetik sehingga para penderita DM dapat menimalkan resiko komplikasi dari DM. Masih banyak kelemahan dari penelitian ini antara lain belum dilakukannya deteksi penurunan sensasi kaki serta pengamatan faktor - faktor lainnya seperti umur dan rendahnya kontrol gula darah, sehingga kedepan perlu dilakukan penelitian lainnya dengan melihat faktor resiko lainnya dan dengan melakukan pemeriksaan sensasi kaki pada penderita DM.

\section{DAFTAR PUSTAKA}

Aaberg, M. L., Burch, D. M., Hud, Z. R., \& Zacharias, M. P. (2008). Gender differences in the onset of diabetic neuropathy. Journal of Diabetes and Its Complications, 22(2), 8387.

Argoff, C.E., Cole,B.E., Fishbain, D.A., \& Irving, G. A. (2006). No TitlDiabetic peripheral neuropathy pain : Clinical and quality of life issuese. Mayo Clinic Proceeding, 81(4), 53.

Black, J.M., \& Hawks, J. . (2009). Medical-surgical nursing: Clinical management for positive outcomes, Eight edition. Singapore: Saunders Elsevier.

Booya, F., Bandarian, F., Larijani, B., Pajouhi, M., Nooraei, M, \& Lotfi, J. (2005). Potential risk factors for diabetic neuropathy: A case control study. BMC Neurol, 5, 24.

Bryant, R., \& Nix, D. (2007). Acute and chronic wound current concept (3rd ed.). St. Louis: Mosby Elsevier.

Day, J. . (2001). Living with diabetes. The diabetes UK guide for those treated with diet and tablets. London: WILEY.

De Meyer, G.R., \& Herman, A. G. (1997). (1997). Vascular endothelial dysfunction. Prog Cardiovasc Dis, 39, 325-342.

Floch, J.P., Doucet, J., Bauduceau, B., \& Verny, C. (2013). Short report: Complications retinopathy, nephropathy, periperal neuropahty and geriatric scale scores in elderly people with type 2 diabetes. Diabetic Medicine, 31, 107-111.

Guyton. (2007). Fisiologi kedokteran. Jakarta: EGC.

Haller, H. (1997). Endothelial function. General Considerations Drugs, 53(1), 1-10.

Hayat, S.A., Patel,B., Khattar,R.S., \& Malik, R. . (2004). Diabetic cardiomyopathy: mechanisms, diagnosis and treatment. Clinical Science, 107, 539-557. 
Ignatavicius, D.D., \& Workman, M. L. (2006). Medical surgical nursing: Critical thinking for collaborative care. Fifth edition. St. Louis: Elsevier Saunders.

Katulanda, P.,Priyanga,R.,Ranil,J.,Gidwin,R.C.,Rezvi,S.,David, R. M. (2012). The prevalance, patterns and predictors of diabetic peripheral neuropathy in a developing country. Diabetology \& Metabolic Syndrome, 4, 21-29.

LeMone, P. \& B. (2008). Medical surgical nursing : Critical thinking in client care.( 4th ed). New Jersey.: Pearson Prentice Hall.

Loughlin, D.T, \& Artlett, C. . (2009). 3-deoxyglucosone-collagen alters human dermal fibroblast migration and adhesion: Implications for impaired wound healing in patients with diabetes. Wound Repair and Regeneration, 17, 739-749.

Mediastuti, T. (2003). Uji Reabilitas skor DNE untuk menentukan diagnosis klinis neuropati diabetika. Yogjakarta: Bagian Ilmu Penyakit Saraf Fakultas Kedokteran Universitas Gadjah Mada.

Meijer, J.W.K., Bosma, E., Lefrandt, J.D., Links, T.P., Smith, A.J., Steward, R. . (2002). Symptom scoring systems to diagnose dystal polyneurophaty in diabetes: The diabetic neurophaty symptom score. Diabet.Med, 19, 962-965.

Smeltzer, S.C., \& Bare, B. . (2008). Brunner \& Suddarth's textbook of medical surgical nursing (11th ed.). Philadelphia: Lippincott Williams \& Wilkins.

Suzuki, E., Kashigawi, A., Nishio, Y., Egawa, K., Shimizu, S., \& Maegawa, H. (2001). Increased arterial wall stiffness limits flow volume in the lower extremities in type 2 diabetics patients. Diabetic Care, 24(12), 2107-2114.

Tesfaye, S. (2006). Diabetic neuropathy. In; Veves A, Giurini JM, LoGerfo FW, editor. The Diabetic Foot, Second Edition. New Jersey: Humaniora Press. 